\title{
Books about Books and Books as Material Artifacts: Metabibliography in Jorge Luis Borges's El jardín de senderos que se bifurcan ${ }^{\mathrm{I}}$
}

La presencia imaginada de libros y su proceso de creación es algo común y corriente en la obra de Jorge Luis Borges. La inclusión de ideas tales como citas bibliográficas inventadas y una biblioteca universal y laberíntica resultan en la descripción de su escritura como un ejemplo supremo de metaficción. Este artículo propone una nueva perspectiva teórica para leer sus ficciones que toma en cuenta la manera en que Borges entiende el libro como un objeto físico.

Palabras clave: Borges, bibliografía, historia del libro, industria editorial, cultura material

The imagined presence of physical books and the process of their creation is a constant in Borges's writings. Notions such as invented bibliographical citations and the labyrinthine conception of an all-encompassing library have caused his work to be described as a prime example of metafiction. This article proposes a new theoretical lens with which to read these types of fictions that takes into consideration how Borges understands the book as a physical object and what this means for his own writings.

Keywords: Borges, bibliography, book history, publishing, material culture

De los diversos instrumentos del hombre, el más asombroso es, sin duda, el libro.

-Jorge Luis Borges, "El libro" (Borges, oral)

During a lecture dedicated to the book, the Argentine writer Jorge Luis Borges makes the claim that he is not interested in the physical form of the book: "Yo he pensado, alguna vez, escribir una historia del libro. No desde el punto de vista físico. No me interesan los libros físicamente (sobre todo los libros de los bibliófilos, que suelen ser desmesurados), sino las diversas valoraciones que el libro ha recibido" (Borges, oral 13-4). Yet his own 
writings, both fiction and nonfiction, seem to tell a different, almost contradictory story with their intricately detailed descriptions of the material object of the book. In this paper, I will situate and analyze a series of short stories by Borges in El jardín de senderos que se bifurcan within the theoretical framework of what I call metabibliography. This framework not only shows how Borges's engagement with books as objects deeply influences his creative fictions, but also helps illuminate editorial decisions he makes within his personal publishing house. In this way, my research joins a community of scholars who place Borges's work within the field of material studies. In particular, Annick Louis has shown how Borges carefully selected materials and "[manipuló] el corpus de sus propios textos" for publishers with an eye toward markets ( 17 ), while Daniel Balderston has demonstrated that Borges's words are constantly shifting and intimately tied to "the materiality of the manuscripts themselves" (How Borges Wrote 2I). My arguments complement their research by foregrounding the need to consider Borges's knowledge of bibliography, or the study of books as physical objects, in his conceptualization and creation of fiction. In other words, I argue that we must take into account not only the specifically chosen textual passages, but also the physical settings of these phrases.

The frequent presence of books, both real and apocryphal, in the pages of Borges's writings has led many critics to define his works as metafictional in nature. For Patricia Waugh, metafiction is "writing which self-consciously and systematically draws attention to its status as an artefact in order to pose questions about the relationship between fiction and reality" (2). ${ }^{2}$ Thus a key aspect of texts of this type is that they "[provide] a critique of their own methods of construction" (Waugh 2). Without question, these definitions can be used to think about most, if not all, of Borges's creative fictions, and, indeed, many scholars have extensively examined the role of metafiction in his works (e.g., Barth, Wicks, Hatlen, Currie, Krysinski, Kressner, Calabrese, and De Toro). I would like to extend and slightly shift the reach of those approaches by an alternative theoretical lens through which we can read and analyze his writings: metabibliography.

In this paper, metabibliography will be seen as a reflective study of how bibliographical analysis is understood, conducted, and written about. The purpose of establishing metabibliography as a theoretical framework is to understand what bibliography might mean in a given context - here, in the work of Borges. Rather than conducting bibliographical analysis, I argue that Borges writes about these types of research methods and uses the evidence that they provide to enrich his creative fictions. A central difference between metafiction and metabibliography is the abstract versus 
the concrete. Although both fields demonstrate a marked interest in the creation process, metafiction focuses on the role of language and the intangible, and metabibliography, in contrast, focuses on an understanding of the physical materials and the tangible. In other words, most metafictional studies acknowledge the fact that texts are made up of words or language, but they often fail to take into consideration "the physical evidence of the passage of texts through the printing process" (Tanselle, Bibliographical Analysis 15).

While the term bibliography most commonly evokes the creation of reference lists, as a field of study it also encompasses the analysis of the physical features, production history, and reception of books as material objects. Given Borges's well-known love of encyclopedias, and, in particular, the eleventh edition of the Encyclopaedia Britannica, these particular volumes serve as the perfect source for a discussion of the field of bibliography. 3 The lengthy four-page entry on "Bibliography and Bibliology" in this volume, authored by the renowned bibliographer Alfred William Pollard, opens with a quick survey of the Greek etymological origins of these terms as "the writing of books" that later transitions to "the writing about books" in the eighteenth century (908). More specifically, Pollard defines bibliography as "the art of the examination, collation and description of books, their enumeration and arrangement in lists for purposes of information, and further with the literature of this subject, i.e. with the bibliography of bibliography" (908). These conceptual divisions point to the central branches of bibliography: enumerative, analytical, descriptive, textual, and historical.4

In applying the term metabibliography to Borges's writings, I seek to highlight the fact that his works contain vast amount of physical details about book production, which demonstrates his deep understanding of the different branches of bibliography.5 What we encounter in the many precisely worded passages of Borges's fictions surpasses the conventional limits of metafiction and constitutes a self-conscious engagement with book production, publication, and circulation that exemplifies his thorough knowledge of bibliography as a field of study. In other words, the ways in which Borges writes about books coincide with the meticulous methods of the examination, collation, description, and arrangement of books that comprise traditional forms of bibliographical inquiry and analysis. To highlight these ideas, I will first identify and analyze several of his texts from El jardín de senderos que se bifurcan that can be classified as metabibliographical in order to show how Borges writes about the physical features of books and how this reveals a deep-seated interest in books as material objects. In particular, throughout my analysis I will align these 
works with elements of descriptive bibliography, textual bibliography, and enumerative bibliography. I then will consider the ways in which this engagement with metabibliography contributes to his elaborate creation of apocryphal works throughout his fiction. By way of conclusion, I employ these concepts to probe Borges's real-life engagement with books through his publishing ventures. What all of these examples demonstrate is the fact that Borges constructed his own works with not only their literary contents, but also their physical features very much in mind.

Many of the short stories in El jardín de senderos que se bifurcan constitute some of Borges's best known writings. As a result, much has been said about this collection and the general engagement that each tale presents with the metafictional concept of self-referential writing. However, there are virtually no critical studies to date about the ways in which Borges deploys the physical features and aspects of real books (in other words, bibliographical data and information) as points of departure for the majority of the works in this collection. ${ }^{6}$ I have chosen to focus on El jardin de senderos que se bifurcan not only because this collection is a touchstone in Borges scholarship, but also because most of the short stories in this work contain references to books and their materiality. In fact, Borges's short prologue to this collection of fiction touches on the practice of writing books about imaginary books and, thus, immediately engages with the idea of metabibliography:

Desvarío laborioso y empobrecedor el de componer vastos libros; el de explayar en quinientas páginas una idea cuya perfecta exposición oral cabe en pocos minutos. Mejor procedimiento es simular que esos libros ya existen y ofrecer un resumen, un comentario... Más razonable, más inepto, más haragán, he preferido la escritura de notas sobre libros imaginarios" (Borges, Ficciones I2).

Even though Borges insinuates that many of the referenced books in $\mathrm{El}$ jardín de senderos que se bifurcan are not real, his analysis of these books is directly informed by bibliographical methods and therefore highlights his practice of metabibliography, or his writing about the bibliographical study of texts.

Readers will find that the very work that opens El jardín de senderos que se bifurcan, "Tlön, Uqbar, Orbis Tertius," presents an interesting bibliographical case. A mysterious reference to an imaginary region, Uqbar, in an article entry of an encyclopedia leads the unnamed narrator, who curiously resembles the real-life Borges and therefore blurs our conceptions of fiction and reality, to search feverishly for any mention or indication of the actual existence of the place. During his search, the narrator 
encounters the region of Tlön and the planet of Orbis Tertius, both of which he discovers to be mere inventions of a team of scholars organized and financed by the millionaire Ezra Buckley. Generally speaking, "Tlön, Uqbar, Orbis Tertius" plays with many common themes that appear throughout a number of Borges's short stories, including the search for absolute truth, doubling, and a myriad of binary oppositions, most notably the difference between history and literature - or the real and the imaginary. Borges himself claims that this story "es quizá el cuento más ambicioso mío. Es la idea de la realidad transformada por un libro" (Carrizo and Borges 222). From a material perspective, this story is nothing short of a bibliographical conundrum: how did these few pages dedicated to Uqbar end up in only one copy of the encyclopedia? What are the unique physical features of the narrator's copy of the Anglo-American Cyclopaedia? Is the typeface used for these pages distinct from the rest of the book? What about the paper? The reader suddenly realizes the importance of these questions and the materiality of the dilemma facing the narrator when he attempts to find a copy of the encyclopedia with the entry on Uqbar. The quest quickly morphs into a wild goose chase in which we see him frantically checking myriad copies of this work throughout Buenos Aires. What we will discover through an analysis of "Tlön, Uqbar, Orbis Tertius" is Borges's conscious engagement with methods of descriptive bibliography, or the study of the physical features and production history of books, through his use of bibliographical data to enhance his narrative. In particular, descriptive bibliography serves as the foundation for virtually all other types of bibliography and, as Pollard writes, is "the ideal toward which all bibliographical work should be directed," since this kind of analysis informs later literary, historical, or even economic work related to the book (909). Describing in detail the physical features of any given book is the most important branch of bibliography and, as a result, acts as the starting point for all other bibliographical pursuits.

After consulting a copy of the Anglo-American Cyclopaedia with no entry on Uqbar, the narrator's friend, Bioy Casares, who also happens to be Borges's real-life best friend, brings his personal copy of the work, with the desired article intact, to the narrator so he can examine the book: "El volumen que trajo Bioy era efectivamente el cuarenta y seis de la AngloAmerican Cyclopaedia. En la falsa carátula y en el lomo, la indicación alfabética (Tor-Ups) era la de nuestro ejemplar, pero en vez de 917 páginas constaba de 921" (Borges, Ficciones 15). The fact that this copy of the AngloAmerican Cyclopaedia contains a half-title page and four more pages of material than any other copy - precisely the pages that correspond to the article on Uqbar - highlights the importance of analyzing not only the text found within a book, but also the physical characteristics of this object, 
which serve as evidence when trying to discern the ways in which this item was produced. Curiously, after analyzing the physical features of this specific copy of the Anglo-American Cyclopaedia, the narrator identifies it as a reprint of the tenth edition of the Encyclopaedia Britannica. While the reference to the tenth edition of the Encyclopaedia Britannica is of great interest in light of Borges's affinity for its later eleventh edition, more intriguing is the use of the term reprint. Bibliographically speaking, "impression and printing are synonymous terms for all copies of the sheets of a book printed by any one run of the presses for one setting of type its equivalent in the form of plates or monotype rolls," and an impression (or reprint) can be created from standing type of the original impression, but, in many cases, corrections, added material, or a new setting of type can be employed for its production (Bowers 374n5).7 More specifically, "impressions may vary somewhat from each other in certain typographical and even textual details and markedly in the size, quality, weight, or color of paper and in the details of the binding" (Bowers 380 ). What is more, impressions are extremely difficult to identify, and, "in the absence of any typographical differentiation, the best clue is likely to be found in the paper used" or, at times, in the bindings (Gaskell 315). In light of the fact that it is difficult to identify a unique impression of any given work, the narrator's description of a specific copy of the Anglo-American Cyclopaedia as such also might allude to the potential circulation of a pirated edition of this work.

Their initial examination of this curious four-page article on Uqbar takes Bioy and the narrator on a textually oriented journey to unearth its publication history. Thus we find them carefully investigating the bibliography that accompanies the article in question and discovering a series of unknown books that lead them to one of the many catalogs of Bernard Quaritch, a real-life bookseller in London and one of the most wellknown figures in the book trade in all of Europe. As one bibliographer notes, Quaritch's cataloging efforts, particularly his last General Catalogue of seventeen volumes (1887-1889), are without doubt "the greatest bibliographical monument ever produced around the stock of a secondhand bookseller" (De Ricci 159). Fernando De Toro also homes in on Borges's reference to Quaritch, yet he uses this allusion to accentuate the blurry divide between reality and fiction, and does not delve into Borges's rationale for selecting this specific bookseller (282ni3). From a bibliographical perspective, the choice of Quaritch's catalog is telling since it is extremely exhaustive and famed for including not just the best editions of a work, but rather all editions of a work. Even apocryphal works, such as the one mentioned by our narrator, might have appeared in one of these catalogs. Unable to unearth new evidence about Uqbar or their mysterious 
encyclopedia, the protagonists finally receive word from a friend that there is a set of the curious multi-volume encyclopedia for sale at a bookstore in Buenos Aires: “Carlos Mastronardi (a quien yo había referido el asunto) advirtió en una librería de Corrientes y Talcahuano los negros y dorados lomos de la Anglo-American Cyclopaedia... Entró e interrogó el volumen XLVI. Naturalmente, no dio con el menor indicio de Uqbar" (Borges, Ficciones ${ }_{17} 7$ ). ${ }^{8}$ Even though the article is missing from the copy they find in the specific bookstore, it is noteworthy that the volumes are described using their physical features (black and gold spines).

This same level of material detail crops up later in the description of a book that the narrator receives in the mail days after the death of Herbert Ashe, a railroad engineer, further complicating his search for the truth about Uqbar: "Era un libro en octavo mayor ... En el amarillo lomo de cuero leí estas curiosas palabras que la falsa carátula repetía: $A$ first [sic] Encyclopaedia of Tlön. Vol. XI. Hlaer to Jangr" (Borges, Ficciones I8-I9).9 The most striking aspect of this passage is the mention of the format of this first [sic] Encyclopaedia of Tlön: a large octavo. The use of this specific bibliographical terminology - whether an octavo, or even a quarto or a folio - seems reserved mainly for sixteenth-, seventeenth-, or even eighteenthcentury title pages, booksellers' catalogs like Quaritch's, or publishers' advertisements, not contemporary fiction. Pollard's entry reminds readers of the complications involved in determining this aspect of a book: ${ }^{\text {IO }}$

The 'size' of a book is a technical expression for the relation of the individual leaves to the sheet of paper of which they form a part. A book in-folio means one in which the paper has been folded once, so that each sheet has made two leaves. In a book inquarto, each sheet has been folded twice so as to make four leaves ... The recognition of what is meant by the size of a book has been obscured by the erroneous idea that the quires or gatherings of which books are made up necessarily consist of single sheets. (909)

Much like the identification of the Anglo-American Cyclopaedia as a reprint of the tenth edition of the Encyclopaedia Britannica, ascertaining the specific format of a book, especially one produced in the nineteenth or twentieth century, is a particularly difficult - if not virtually impossible - task. Similar mentions of the format of examined books crop up throughout other short stories in El jardín de senderos que se bifurcan, which serves to emphasize the foundational importance of bibliographical detail.

The closing postscript of "Tlön, Uqbar, Orbis Tertius" solidifies the meaningful engagement that this short story maintains with descriptive bibliography, since this section of the text presents readers with the solution 
to the enigma of the four-page article on Uqbar that is discovered through a close examination of the encyclopedias in question and their printing history. More specifically, we learn of the production of the secret edition of the encyclopedia of Tlön and how these volumes circulated at first only among the members of Ezra Buckley's secret society, and then were later located in places as far away as Nashville, Tennessee. This, in turn, resulted in an explosion of "manuales, antologías, resúmenes, versiones literales, reimpresiones autorizadas y reimpresiones piráticas" of the original (Borges, Ficciones 35). ${ }^{.1}$ Understanding the history of the ways in which these mysterious encyclopedias have circulated and, consequently, have mutated underscores the role of bibliography in piecing together the physical evidence present in each book to recreate the circumstances of production for the unique copy of the Anglo-American Cyclopaedia that makes its way into the hands of Bioy and his friend. In short, we can identify a clear engagement with descriptive - as well as analytical - bibliography in this short story. Borges relies on this type of analysis to foreground the complex system of bringing any given text into physical existence, since it must pass through various hands, from editors and graphic designers to typesetters and printers, before it reaches the reader. Thus, much like DNA replication that continually introduces the possibility of mutation, books are the product of many highly orchestrated human interactions that can result in the introduction of errors at any moment in the entire process that tell the story of each object's unique creation.

A second story from the collection, "Pierre Menard, autor del Quijote," is often cited for its questioning of key literary-critical concepts such as authorship, interpretation, and reader-response. Yet, throughout the pages of this work, we also find an engagement with bibliography. For instance, at the start of the story the narrator draws the reader's attention to the fact that Menard's oeuvre "es fácilmente enumerable" and then proceeds to list his publications chronologically in an effort to correct a previous "catálogo falaz" that lacked a number of his works (Borges, Ficciones 48, emphasis added). In the process, the narrator produces what, according to Pollard or any other bibliographer, would be the perfect example of an enumerative bibliography.12 In addition, the central crux of this short story, Pierre

Menard's literal (re)writing of the Quijote perfectly aligns with issues of the examination and collation of books as well as their description, which are all inherently a part of bibliography and, more broadly, the creation of critical editions of works. As a result, through a close analysis of "Pierre Menard, autor del Quijote," I hope to show how the clear contemplation of ideas related to the production of a text in this work functions as another example of metabibliography. More broadly speaking, considering the 
metabibliographical aspects of "Pierre Menard, autor del Quijote" will help us to better understand and further enrich its literary-critical engagements with the ideas of canon formation, literary traditions, and cultural markets. As Balderston notes in his analysis of this short story, "the search for the real in Borges's texts," which is precisely the aim of bibliographical research, "will no doubt be one of the most fruitful paths for Borges criticism in the coming years" ("Insect-Like" I34).

Immediately following the enumerative bibliography of Menard's published works, the reader is introduced to his latest literary project, namely, "escribir un Quijote contemporáneo" (52). The narrator is quick to clear up any confusion regarding the nature of this project, which initially might appear to be a creative work in the style of the Quijote. In fact, we discover Menard aims to "producir unas páginas que coincidieran - palabra por palabra y línea por línea - con las de Miguel de Cervantes" (Borges, Ficciones 52). After reading this description of Menard's next literary project, readers might think of it as an exercise in creative writing or a simulation of medieval practices of copying or plagiarism. As we read more about the entire process behind Menard's Quijote in the ensuing pages another thought springs to mind: he is crafting nothing other than an edition of this work and, thus, engaging directly with textual bibliography. In general terms, textual bibliography, also referred to as scholarly editing, looks to insight gathered from texts themselves, such as design features and variants, to prepare new documents that are either critical, which involves making emendations or changes in order to show authorial intention or a complete textual history of the document, or diplomatic, which involves no emending of the text. In a strange turn of events, Menard himself identifies these same two distinct methods of textual bibliography a few pages later: "Mi solitario juego está gobernado por dos leyes polares. La primera me permite ensayar variantes de tipo formal o psicológico; la segunda me obliga a sacrificarlas al texto 'original' y a razonar de un modo irrefutable esa aniquilación" (Borges, Ficciones 55). Menard's compositional outcome - his Quijote - will be determined by one of these two "leyes polares" that map onto the previously described scholarly editions. Thus, it will be either a critical edition, which allows for variants ("me permite ensayar variantes de tipo formal o psicológico"), or a diplomatic edition, which does not allow for variants ("me obliga a sacrificarlas al texto 'original"). As we shall see below, the ways in which Menard undertakes his Quijote project directly correspond with the creation of a diplomatic edition of a work.

First is his profound interest in understanding the social and historical moment of Cervantes. He strives to recreate this moment in time for a heightened awareness of the forces placed on this Spaniard's writing 
process: “Conocer bien el español, recuperar la fe católica, guerrear contra los moros o contra el turco, olvidar la historia de Europa entre los años de I602 y de I9I8, ser Miguel de Cervantes" (Borges, Ficciones 52-3). ${ }^{\mathrm{I3}}$ Menard notes that such a procedure is extremely difficult and virtually impossible, but he will attempt it nonetheless. What is more, he uses the specific verb "componer" to describe his actions, which has the double meaning of composing (or writing) a text and setting a text in type. ${ }^{\mathrm{It}}$ The sheer fact that both works "son verbalmente idénticos" also connects Menard's project with the creation of a diplomatic edition. Finally, when discussing the reception of Menard's work, the narrator comments that some individuals saw it as a literal transcription of the Quijote, which further links the methods analyzed in this short story with those of textual bibliography, since many non-critical editions will consist of nothing more than a series of facsimiles with their accompanying transcriptions. "Pierre Menard, autor del Quijote" serves as the perfect example of Borges's metabibliography, or self-conscious writing about bibliography, since many theories and methods of bibliography operate at the heart of this short story and provide him with a unique point of departure for his creative fictions. On a deeper level, many of the metabibliographical and editorial issues at stake in this short story both complement and complicate its established literary-critical interpretations. For instance, each work included in any sort of canon must be evaluated for not only its literary qualities, but also its textual and physical qualities of composition.

"El acercamiento a Almotásim" and "Examen de la obra de Herbert Quain," two additional stories from El jardín de senderos que se bifurcan, also incorporate an awareness of bibliographical analysis, including elements of enumerative bibliography and descriptive bibliography. At the start of "El acercamiento a Almotásim," the first edition ("editio princeps") of the work of the same name is printed on paper that "era casi papel de diario," and within the first few months of its publication, "el público agotó cuatro impresiones de mil ejemplares cada una" (Borges, Ficciones 38). ${ }^{15}$ The narrator of this short story also mentions the publication of an "edición ilustrada ... que acaba de reproducir en Londres Víctor Gollancz," a major mid-twentieth century British publisher (Borges, Ficciones 38). Borges's decision to include the name of an authentic publishing firm, as opposed to fabricating one, highlights his interest in blurring not only the division between reality and fiction, but also the world of print culture and its production. These mimetic details further emphasize Borges's knowledge of the complex world of book publishing and circulation. Thus, we find that even the references to places in which books are produced in any given Borges short story is worth further examination for the historical 
significance that they might bring to light. ${ }^{16}$ Furthermore, after detailing the first printing and subsequent reviews of Acercamiento a Almotásim, the narrator of the short story of the same name notes his engagement with textual bibliography in compiling "un apéndice, que resume la diferencia fundamental entre la versión primitiva de 1932 y la de 1934 " (Borges, Ficciones 38). ${ }^{17}$

A similar situation occurs in "Examen de la obra de Herbert Quain," in which the ultimate flop of the protagonist's novel The God of the Labyrinth is due to failed marketing strategies and the publication of a competing novel by Ellery Queen. ${ }^{8}$ Since this particular short story masquerades as a type of obituary after the death of Herbert Quain, there are passing references to several of his publications accompanied by a brief summary and/or review of them, a feature that directly echoes much of Borges's work for the magazine El Hogar from 1936 to 1939. In fact, the enigma at the heart of Herbert Quain's The God of the Labyrinth is its textual similarity to Borges's review of Richard Hull's Excellent Intentions in the April 15, 1938 issue of El Hogar.19 Nashieli Marcano expertly links this particular short story to the field of bibliography for its reliance on methods of textual bibliography, which serve to authenticate Quain's work: "El hallazgo [de lo auténtico] se hace posible por medio de la creación de una bibliografía textual que le facilita al narrador-reseñista de 'Examen' justificar la publicación de la obra de Quain (mediante la mención de fechas) y, a la vez, determina la inestabilidad textual tanto de Quain como de Borges (por sus revisiones de 'Examen') en su empresa literaria” (466). Reading these short stories through a metabibliographical lens allows us to grasp important aspects of Borges's writings that might otherwise go unnoticed or dismissed as mere physical details. In fact, these metabibliographical elements of Borges's work accentuate many of the larger philosophical themes that he most frequently writes about, such as authenticity, reality, and truth.

"La Biblioteca de Babel," also collected in El jardín de senderos que se bifurcan, contains many clear instances of metabibliography. Within the hexagonal rooms of this library not only are all of the books described as uniform, but their entire physical composition is described in great detail: "cada libro es de cuatrocientas diez páginas; cada página, de cuarenta renglones; cada renglón, de unas ochenta letras de color negro. También hay letras en el dorso de cada libro" (Borges, Ficciones 9I). In addition, all of the books "constan de elementos iguales: el espacio, el punto, la coma, las veintidós letras del alfabeto" (Borges, Ficciones 93-4). Even though all of these books are uniform and composed in exactly the same way, the narrator of this short story specifically stresses the fact that "no hay, en la vasta Biblioteca, dos libros idénticos," which touches on the bibliographical 
idea that every book is a unique physical object (Borges, Ficciones 94). This idea of both textual and physical differences between copies of books is later suggested toward the close of the story in which the narrator reminds readers that even facsimiles of the works in this library differ from one another: "cada ejemplar [es] único, irremplazable, pero (como la Biblioteca es total) hay siempre varios centenares de miles de facsímiles imperfectos: de obras que no difieren sino por una letra o por una coma" (Borges, Ficciones 96). While facsimiles should not differ in content from their original sources, they can differ - and often do - in a physical sense. Thus, from a bibliographical perspective, the changes in scale, paper, quality of image, and coloration among facsimiles will always vary and, as a result, point to how no two copies in this library are the same.

Many of the key aspects of this particular short story show a marked engagement with a number of branches of bibliography such as descriptive bibliography (in the detailed description of each volume in the library) and enumerative bibliography (in the precise and methodical arrangement of all of the books in this library). However, the most important form of bibliography that permeates the entirety of "La Biblioteca de Babel" is the bibliography of bibliographies or the systematic indexing - and organization - of all books for future ease of discovery, which, I argue, lies at the heart of not only El jardín de senderos que se bifurcan, but also of much of Borges's oeuvre as a whole. ${ }^{20}$ To begin with, in addition to the great sense of order and classification of the works in the library (and of the library in general), every person throughout the story is described as a librarian as well, which further emphasizes the central role of books and their study for this work. What is more, an overarching message of "La Biblioteca de Babel" is that every book is rare and, as result, every book should be catalogued and treated with care. This concept arises when the narrator of this short story describes how the "Purificadores" invaded the library on several occasions to cleanse the library of books that they considered "inútiles," which resulted in "la insensata perdición de millones de libros" (Borges, Ficciones 96). Pollard evinces a similar sentiment in his own writings: "if [books] are to be of any use, they must be as living friends or acquaintances, and the whole art of forming and keeping a library consists in treating them on this footing, alike mentally and materially" (Books 8). Part of what makes this fictitious library intriguing is its seeming visual uniformity that, upon closer inspection, turns out to be a mere illusion since, as noted earlier, no two books in the entire library are exactly the same.2 Thus, the adage that appearances can be deceiving rings true when considering the supposed uniformity of any two given books. As historical, social, and economic artifacts, every book presents readers with unique evidence regarding their 
production and place in a larger literary context and, thus, the physical features must be examined.

Throughout "La Biblioteca de Babel" there are several references to a certain book that serves as the perfect summary or condensation of every other book in the library that exists or that ever will exist, which is equivalent to a bibliography of bibliographies. This is the "libro total" that the narrator describes at length. This is precisely the book that outlines the system through which individuals can find each and every book in the library, much like the Dewey Decimal System: "Para localizar el libro A, consultar previamente un libro B que indique el sitio de A; para localizar el libro B, consultar previamente un libro C, y así hasta lo infinito" (Borges, Ficciones 97). The vademecum, or manual, that surfaces in the short story's closing footnote also aligns with a bibliography of bibliographies: "bastaría un solo volumen, de formato común, impreso en cuerpo nueve o en cuerpo diez, que constara de un número infinito de hojas infinitamente delgadas" (Borges, Ficciones Ioo). Interestingly, Pollard classifies the bibliography of bibliographies as an example of a universal bibliography, which undoubtedly corresponds to the sense of an all-encompassing library as depicted in "La Biblioteca de Babel." 22 Pollard also notes in his entry in the Encyclopaedia Britannica that "universal bibliography was recognized as an impossibility," an observation that plays into the inherent dichotomy of fiction and reality that crops up in light of the narrator's notion of an infinite library (9II).

When I introduced the idea of bibliography and metabibliography at the start of this essay, I turned to Pollard's detailed entry in the eleventh edition of the Encyclopaedia Britannica, choosing this apt source for the high probability that Borges would have read these exact words at one point in his life. While the strong chance that Borges consulted this source makes its selection particularly relevant for my current study, I also chose Pollard's words, as opposed to those of any other bibliographer, for two of his major contributions to the field: his systematic organization of books at the British Museum and his role in the completion of A Short-Title Catalog of Books Printed in England, Scotland, and Ireland, and of English Books Printed Abroad 1475-1640 (1926). These two works, the products of a lifetime of dedicated scholarship, point to the inspiration that Borges might have drawn from a figure like Pollard in his writing of El jardín de senderos que se bifurcan. His organizational methods, his bibliography of bibliographies, and his clear explications of the varying branches of bibliography suggest that Pollard enters into direct dialogue with Borges. That is to say, the "Hombre del Libro" who resides at the heart of "La Biblioteca de Babel" is someone who is responsible for the complete systematization of the books 
and spaces in this library and, as a result, bears a striking resemblance to a figure like A. W. Pollard.

While Borges's writings demonstrate a conscious engagement with bibliographical methodologies, even more compelling are the editorial decisions that he makes within his personal publishing house, which reveal an understanding of the historical traditions of book production. From early on in his literary career, Borges was not only involved with the initial stages of crafting a manuscript to be sent to a publisher, but also immersed in the more editorial tasks of correcting proofs and even setting type to be printed. ${ }^{23}$ In an interview with Antonio Carrizo, recorded in Borges el memorioso (1979), the Argentine writer recalled the following from his time as co-director of the Revista Multicolor de los Sábados, the literary supplement to the newspaper Crítica: "me gustaba mucho trabajar con los obreros en el taller, con los linotipistas. Y aprendí a leer los linotipos, como un espejo. Y aprendí a armar una página también" (2I8). In this same interview Borges was asked if he enjoyed this environment to which he responded, tellingly, "Sí; me gustaba mucho. El ambiente de una imprenta es muy, muy agradable. Armar páginas, corregir pruebas: todo eso lo hacía yo" (Carrizo 218). Ulises Petit de Murat, co-director with Borges of this literary supplement, confirms this sentiment in his memoir: "Borges accede a un mundo nuevo. Se le exige en la imprenta, junto a mí, que disponga la colocación de un grabado; que complete una página; que redacte allí mismo, cosa que no hubiera nunca soñado en hacer" (I4O-I). Thus we find inherent elements of metabibliography - or an awareness of the production processes that books undergo - by examining not just Borges's creative fictions, but also his employment history and daily activities behind the scenes. That is to say, while working for a number of different journals and newspapers, Borges was invested in both the material form and the literary content of the works that he was helping to produce. These early jobs revealed to him how books were made, exposed him to the financial and material constraints placed on each book's unique physical form, and ultimately provided him with a deep knowledge of the historical processes of book production. ${ }^{24}$

The skills that Borges acquired from directing and editing larger scale projects during the first half of the twentieth century explain the ease with which he and his close friend, Adolfo Bioy Casares, were able establish an apocryphal publishing house, the Editorial Oportet \& Haereses, which produced three uniquely beautiful volumes: Dos fantasías memorables (1946), Un modelo para la muerte (1946), and Nueva refutación del tiempo (1947). ${ }^{25}$ Borges's selection of distinct physical features for these works reveals his preference for certain bibliographical trends over others and 
provides further evidence for his engagement with books as material objects. Thanks to his behind-the-scenes editorial positions, Borges occupied a key position in the publishing world as a writer who was aware of the newest technologies and methods of print production, as well as the elements of book design and manufacturing. In essence, Borges challenged the traditional models of an author's relationship to the book world - the overly engaged author and the overly distant author - and demonstrated an understanding and appreciation of labor practices and material production in the literary marketplace.

The most striking aspect of the Editorial Oportet \& Haereses's works is that they are all well-made, beautiful editions that seem to echo many avantgarde tendencies toward art for art's sake. In other words, the physical features of these books, from their marbled covers to their modern typefaces, show a clear attention to detail and point to an interest in the history and creation of books. More specifically, the first two works are quarter bound in a blue cloth with marbled paper on the front and backboards, which was a common style of binding throughout Europe and the United States, yet was much less common in Argentina. Coupled with this particular binding is the presentation of the title and author name on a small piece of paper adhered to the spine. Printed paper spine labels did not become commonplace in the book world until the eighteenth century when publishers and wholesalers began to use them as a kind of expedient packaging for the works they produced. These add-ons were intended to be a temporary fix until the potential buyer was able to remove the somewhat shabby publishers' bindings for new, more elegant, materials. William Morris's Kelmscott Press, however, favored similar quarter binding with paper boards and printed spine labels at the end of the nineteenth century and, in the process, "set a fashion among other publishers, so that, for a generation or more after Morris's death, English readers were afflicted with a plague of books issued in board covers with blue or grey paper" (Peterson I2I). With their peculiar use of similar printed spine labels on books that have more elegant marbled papers, Borges and Bioy Casares showcase their awareness of historical bibliography and, in the process, demonstrate their knowledge of how books are made and how books should be used. In essence, Borges's metabibliography exists in both the literary contents of his short stories and in the more material aspects of his works' bindings, typography, and paper. Borges's understanding of bibliographical concerns extends far beyond an initial inspiration for a series of short stories; rather, his knowledge of bibliographical traditions and tendencies in world book history and their respective markets leads to the complex incorporation of 
certain physical features over others when editing, composing, and producing works for his very own publishing house.

In direct contradiction to his statements in the aforementioned 1978 lecture, Borges seems in fact to have always had a keen interest in books and the printed text. From the formative years he spent within the walls of his father's library to his places of employment during the first half of the twentieth century, the physical mediums of books are always a constant. Dissecting and analyzing the ways in which he makes references to the physical features of these mediums in his own writings reveals a profound and long-standing engagement with books and, by extension, bibliography. He uses this detailed knowledge of the material characteristics and components of books to aid in his creation of the apocryphal texts and imaginary volumes that appear throughout his works, and also to determine the physical features of the real books that he produced with the Editorial Oportet \& Haereses. Borges himself further emphasizes the uniquely inspirational quality of books in the same 1978 lecture cited earlier:

De los diversos instrumentos del hombre, el más asombroso es, sin duda, el libro. Los demás son extensiones de su cuerpo. El microscopio, el telescopio, son extensiones de su vista; el teléfono es extensión de la voz; luego tenemos el arado y la espada, extensiones de su brazo. Pero el libro es otra cosa: el libro es una extensión de la memoria y de la imaginación. (Borges, oral 13)

Thus, it is the book (both in terms of its production process and its completed physical form) that lies at the heart of Borges's works. It is the book that speaks volumes about his formation as a writer and his intricate creation process. In a somewhat ironic turn of events, it is through a reflection on Borges's understanding of bibliographical analysis, or a metabibliographical reading of his works, that we discover his interest in the book as a physical object.

Princeton University

NOTES

I I owe a great deal to Andrew A. Anderson, James P. Ascher, Harrison P. Frye, Micah McKay, David Whitesell, Nicholas Wolters, and David Vander Meulen for all of their invaluable comments that helped me work through the theoretical underpinnings and overall structure of this article. 
2 Linda Hutcheon expands on this foundational idea in her A Poetics of Postmodernism: History, Theory, Fiction by introducing the concept of "historiographical metafiction," which harmoniously melds literature, history and theory into one: "that is, its theoretical self-awareness of history and fiction as human constructs (historiographic metafiction) is made the grounds for its rethinking and reworking of the forms and contents of the past" (5). More recent scholarship takes this idea even further by showing how metafictional narratives help us "to understand ourselves, our status as human beings, our identities, and our experience and interpretation of reality" (Amago 3I).

3 Sometime during $\mathbf{1 9 2 9}$, Borges won a literary prize for Cuaderno San Martín (I929), and, with the money received, he purchased a "second-hand set of the Eleventh Edition of the Encyclopaedia Britannica" (Borges, "Autobiographical Notes" 74).

4 James P. Ascher succinctly describes each of these branches as follows: "Enumerative bibliography is the synthetic listing of knowledge; analytical bibliography reconstructs production processes; descriptive bibliography gives detailed accounts of physical structures; textual bibliography endeavors to reconstruct texts and their transmission; and historical bibliography means the historical study of books."

5 It is important to highlight the relationship between bibliography and literary studies as well. Ronald B. McKerrow describes the value of learning basic skills of bibliography for improving literary analysis, including an understanding of the relationship between the pages in a book and their bindings. He also describes the hopeful eradication of erroneous modes of thinking such as conceiving of the pages of a book as being printed one after the other in sequential order (McKerrow, "Notes" 220). These two ideas clearly connect with McKerrow's claim that a book should be "regarded not as a unit, but as an assemblage of parts each of which is the result of a clearly apprehended series of processes" ("Notes" 22I).

6 Fernando De Toro's article on this collection, which focuses heavily on "Tlön, Uqbar, Orbis Tertius," notes the presence of real people and real books throughout this particular short story, but he does not dissect the use of these real references to determine why Borges might have referred to specific individuals or works. More recently, Nashieli Marcano relies on several branches of bibliography to discuss textual instability in "Examen de la obra de Herbert Quain," but she does not discuss why Borges might have engaged with this field of study or what it might tell us about his perceptions of books as objects of study.

7 Undoubtedly there are geographic and profession-specific preferences for the use of the terms (re)printing and (re)impression. According to Fredson 
Bowers, " $[p]$ rinting is the term ordinarily used by the book trade, ... the word impression is preferable for bibliographical writing" (374n5, emphasis added). For more information regarding the differences between an edition, an impression, an issue, and a state, see Tanselle, "The Bibliographical Concepts of 'Issue' and 'State."'

8 Nicolás Helft has linked these black and gold spines with the eleventh edition of the Encyclopaedia Britannica, but they could just as easily match up with the tenth (or an even earlier) edition, especially when we consider the drastic physical changes that this work underwent in the eleventh edition. More specifically, the most novel feature of the eleventh edition of this encyclopedia was its use of India paper, which made the volumes thinner, lighter, and easier to handle and read. In addition, these new volumes were available in four different binding styles with the India paper and three with ordinary book paper.

9 In addition to being a character in "Tlön, Uqbar, Orbis Tertius," Herbert Ashe was also a real-life friend of Borges's father, which further serves to blur the distinctions between reality and fiction.

IO Gérard Genette also touches on this important bibliographical concept of format-or, as he calls it, " $[\mathrm{t}]$ he most all-embracing aspect of the production of a book" - in his foundational work Paratexts (I7). Like Pollard, he provides readers with a succinct description of various formats of books from a folio ("folded once, hence two leaves, or four pages per sheet" [I7]) to an octavo ("eight leaves" [I7]) or even an octodecimo.

II In including such a curious detail about modes of circulation in this short story, Borges might also be parodying a strictly limited bibliophile edition by commenting on the small print run of this secret edition.

I2 "He dicho que la obra visible de Menard es fácilmente enumerable. Examinado con esmero su archivo particular, he verificado que consta de las piezas que siguen" (Borges, Ficciones 48). The phrase "obra visible" appears on three separate occasions throughout the work when discussing the writings of Menard, which seems to show a similar link to bibliography since, in its broadest sense, it is the study of books as observable physical objects (Borges, Ficciones 47, 48, 5I).

I3 Even though the narrator does not inform his readers of the specific edition that Pierre Menard uses for his edition, it is clear that he is working with a printed form, as opposed to original manuscript material.

I4 Here again we see the ambiguity between manuscripts and printed forms in the creation process.

I5 This latter quoted passage involving print impressions further emphasizes Borges's understanding and use of bibliographical data and methodology. 
I6 One such references appears in "El milagro secreto" in which a playwright, Hladík, is arrested for his translation of the Sepher Yezirah "para la editorial Hermann Barsdorf; el efusivo catálogo de esa casa había exagerado comercialmente el renombre del traductor" (Borges, Ficciones 166). Similar to the British publishing firm that appears in "El acercamiento a Almotásim," Hermann Barsdorf is also a real publishing house (in this case in Germany). More interesting, perhaps, is the fact that, during the Second World War, many Nazi soldiers used catalogs from this latter German publishing house to identify Jewish authors and, subsequently, persecute them. Thus, the specific editions of real works that Borges mentions throughout any number of his short stories and essays deserve a closer look.

I7 The specific verb "examinar" appears in the next line of the text, which also connotes an engagement with methods of descriptive bibliography, since the bibliographical description of a specific edition of a book requires scholars to examine as many copies of the same edition as possible for their physical features such as typographical variants, inconsistencies in inking, or even differences in paper or types of binding. The fact that Borges chose to write "examinar" instead of "leer" or even "interpretar" points to an understanding of the importance of bibliographical analysis for approaching material objects and their unique histories. Also see Tanselle, "A Description of Descriptive Bibliography."

I8 Here again we see the conflation of real and imaginary worlds with the juxtaposition of the invented Herbert Quain and the real detective fiction author Ellery Queen (a pseudonym for Daniel Nathan and Emanuel Benjamin Lepofsky).

I9 The passage in question from "Examen de la obra de Herbert Quain" is the following: "todos creyeron que el encuentro de los dos jugadores de ajedrez había sido casual. Esa frase deja entender que la solución es errónea. El lector, inquieto, revisa los capítulos pertinentes y descubre otra solución, que es la verdadera. El lector de ese libro singular es más perspicaz que el detective" (Borges, Ficciones 83); Borges's review in El Hogar states the following: “...'y todos creyeron que el encuentro de ese hombre y de esa mujer había sido casual' - que indicara o dejara suponer que la solución era falsa. El lector, inquieto, revisaría los capítulos pertinentes y daría con otra solución, con la verdadera. El lector de ese libro imaginario sería más perspicaz que el 'detective'" (26).

20 In contrast with a single enumerative bibliography, or a list of reference works, a bibliography of bibliographies amasses all existing (enumerative) bibliographies on a common subject, theme, or area of research. While metabibliography can linguistically refer to a bibliography of bibliographies, I do not use this theoretical term as such, but rather conceive of 
metabibliography as a self-conscious writing about the various branches and types of bibliographical analysis.

2I This idea also is reinforced when the narrator of "La Biblioteca de Babel" critiques the peculiar sentiments of bibliophiles who simply worship books, yet "no saben descifrar una sola letra" (Borges, Ficciones 99).

22 The other, rather different, idea involved here is that of the Infinite Monkey Theorem, which posits that a monkey hitting a keyboard at random for an infinite period of time will produce all possible texts.

23 Along with his job as co-director of the literary supplement for the magazine Crítica (1933-1934), Borges's knowledge of the ins and outs of publishing also can be traced to his involvement with a number of different avant-garde magazines from the i92os, including Martín Fierro, Proa, and Prisma.

24 Laura Rosato and Germán Álvarez have noted Borges's affinity for certain types of books in his own library, which suggests another level of bibliographical awareness: "Ediciones antiguas, ... la tipografía gótica, los comentarios, estudios, traducciones o introducciones realizadas por intelectuales de renombre, ... éstas son algunas de las características generales que surgen" (25).

25 I use the term apocryphal here to mean rare or secretive: "in its earliest use it was applied in a laudatory sense to writings, (I) which were kept secret because they were the vehicles of esoteric knowledge which was too profound or too sacred to be imparted to any save the initiated ... (2) But the word was applied to writings that were kept from public circulation not because of their transcendent, but of, their secondary or questionable value ... (3) The word came finally to mean what is false, spurious, bad, heretical" (Charles I70).

WORKS CITED

A m a g o, s a m u L. True Lies: Narrative Self-Consciousness in the Contemporary Spanish Novel. Lewisburg: Bucknell UP, 2006.

ASCHER, JA m Es P. "Bibliographical Awareness in Art: Joel Swanson's Spacebar."

Media Archaeology Lab. 3 December 2013. Web.

BALDERSTON, DAN IEL. "'His Insect-Like Handwriting': Marginalia and

Commentaries on Borges and Menard." Variaciones Borges 3I (2011): I25-36.

-. How Borges Wrote. Charlottesville: U Virginia P, 2018.

B A R t , J J H. " "The Literature of Exhaustion." Atlantic Monthly 220.2 (1967): 29-34.

в ORgES, Jorge Luis. “Autobiographical Notes.” The New Yorker, i9 September

I970: 40-99.

—. Borges, oral. Buenos Aires: Emecé Editores, I979.

—. El jardín de senderos que se bifurcan. Buenos Aires: Sur, I94I. 
-. Ficciones. Madrid: Alianza Editorial, 1995.

—. "Libros y autores extranjeros. Guía de lecturas." El Hogar, 15 abril 1938, p. 26.

—. Nueva refutación del tiempo. Buenos Aires: Editorial Oportet \& Haereses, 1947.

BOWERS, FREDSON. Principles of Bibliographical Description. New Castle: Oak Knoll $\mathrm{P}, 2 \mathrm{OI2}$.

Calabrese, elisa. “'Pierre Menard...' o la metaficción como lectura." CELEHIS 20.22 (2OII): 3I-47.

CARRIzo, antonio and Jorge luis borges. Borges el memorioso: Conversaciones de Jorge Luis Borges con Antonio Carrizo. México: Fondo de Cultura Económica, 1997.

charles, robert henry. "Apocryphal Literature." Encyclopaedia Britannica. Itth ed. New York: The Encyclopedia Britannica Company, I910-I9II: 175-I83. CURRIE, Mark, ed. Metafiction. New York: Longman, 1995.

DE RICCI, SE YM OUR. English Collectors of Books and Manuscripts (I530-1930) and Their Marks of Ownership. Bloomington: Indiana UP, 1960.

DE TORO, FERnANDO. "Borges and the Construction of 'Reality." Semiotica 195 (2013): 277-304.

DOMECQ, HONORIO B UST OS. Dos fantasías memorables. Buenos Aires: Editorial Oportet \& Haereses, 1946.

GaS KE LL, PHILIP. A New Introduction to Bibliography. New Castle: Oak Knoll P, 2012.

Gass, wi liam h. "Philosophy and the Form of Fiction." Fiction and the Figures of Life. New York: Knopf, 1970: 3-26.

genette, gérard. Paratexts. Cambridge: Cambridge UP, 1997.

hat le n, Bur to n. "Borges and Metafiction." Simply a Man of Letters. Orono: U of Maine at Orono P, 1982: 13I-54.

HELFT, NICOLÁs. "History of the Land Called Uqbar." Variaciones Borges 15 (2003): I5I-80.

h U TCHE ON, Linda. A Poetics of Postmodernism: History, Theory, Fiction. New York: Routledge, I988.

KRESSNER, ILKA. "Space as Metafictional Marker: Borges's “Tema del traidor y del héroe' and Bertolucci's Strategia del ragno." Bulletin of Hispanic Studies 87.8 (2010): 977-994.

Kry SinS Ki, Wladimir. "Borges, Calvino, Eco: The Philosophies of Metafiction." Literary Philosophers: Borges, Calvino, Eco. Eds. Jorge J. E. Gracia, Carolyn Korsmeyer, and Rodolphe Gasché. New York: Routledge, 2002: 185-204. LouIs, A N NiCk. Jorge Luis Borges: Obras y maniobras. Santa Fe: Ediciones Universidad Nacional del Litoral, 2013.

marCan O, NASH IE LI. "La reseña bibliográfica y la inestabilidad textual en 'Examen de la obra de Herbert Quain' (194I), de Jorge Luis Borges." Revista de Estudios Hispánicos 50.2 (2016): 463-83. 
M C K E R R W, R ONA L D B. An Introduction to Bibliography for Literary Students.

Oxford: Clarendon P, 1927.

—. "Notes on Bibliographical Evidence for Literary Students and Editors of English

Works of the Sixteenth and Seventeenth Centuries." Transactions of the

Bibliographical Society I2 (I9II-I3): 2II-3I8.

Peterson, willia m S. The Kelmscott Press: A History of William Morris's

Typographical Adventure. Oxford: Claredon P, i991.

Petit de murat, ulis es. Borges, Buenos Aires. Buenos Aires: Municipalidad de la

Ciudad de Buenos Aires, Secretaría de Cultura, i980.

POLlard, AlFRED William. "Bibliography and Bibliology." Encyclopaedia

Britannica. IIth ed. New York: The Encyclopedia Britannica Company, I910-1911: 909-912.

-. Books in the House. London: Arthur L. Humphreys, 1907.

rosato, laura AN d GERMÁn Álvarez. Borges, libros y lecturas. Buenos Aires:

Biblioteca Nacional, 20 IO.

SUÁREZ L YNCH, BENIT o. Un modelo para la muerte. Buenos Aires: Editorial Oportet \& Haereses, 1946.

TAnS el e, G. Th m as. Bibliographical Analysis. A Historical Introduction. New York: Cambridge UP, 2009.

—. "The Bibliographical Concepts of 'Issue' and 'State'." The Papers of the Bibliographical Society of America 69.I (1975): I7-66.

—. "A Description of Descriptive Bibliography." Studies in Bibliography 45 (I992): I30.

Wa U G H, PA Ricia. Metafiction: The Theory and Practice of Self-Conscious Fiction. New York: Methuen, I984.

W I C K S, U L R IC H. "Borges, Bertolucci, and Metafiction." Narrative Strategies. Eds.

Syndy M. Conger and Janice R. Welsch. Macomb: Western Illinois UP, I980: 1936. 